\title{
Muscarinic receptors participation in angiogenic response induced by macrophages from mammary adenocarcinoma-bearing mice
}

\author{
Eulalia de la Torre1, Lilia Davel1, María A Jasnis', Tomomi Gotoh², Eugenia Sacerdote de Lustig ${ }^{1}$ \\ and María E Sales ${ }^{1}$
}

\author{
${ }_{1}^{1}$ Departamento de Inmunobiología, Instituto de Oncología A.H. Roffo, Universidad de Buenos Aires, Buenos Aires, Argentina \\ 2Department of Molecular Genetics, School of Medicine, Kumamoto University, Kumamoto, Japan \\ Corresponding author: Maria E Sales, mesales@2vias.com.ar
}

Received: 28 Jul 2004 Revisions requested: 2 Sep 2004 Revisions received: 30 Nov 2004 Accepted: 26 Jan 2005 Published: 4 Mar 2005

Breast Cancer Research 2005, 7:R345-R352 (DOI 10.1186/bcr1005)

This article is online at: http://breast-cancer-research.com/content/7/3/R345

(c) 2005 de la Torre et al.; licensee BioMed Central Ltd.

This is an Open Access article distributed under the terms of the Creative Commons Attribution License (http://creativecommons.org/licenses/by/ 2.0), which permits unrestricted use, distribution, and reproduction in any medium, provided the original work is properly cited.

\begin{abstract}
Introduction The role of macrophages in tumor progression has generated contradictory evidence. We had previously demonstrated the ability of peritoneal macrophages from LMM3 murine mammary adenocarcinoma-bearing mice (TMps) to increase the angiogenicity of LMM3 tumor cells, mainly through polyamine synthesis. Here we investigate the ability of the parasympathetic nervous system to modulate angiogenesis induced by TMps through the activation of the muscarinic acetylcholine receptor (mAchR).

Methods Peritoneal macrophages from female BALB/c mice bearing a 7-day LMM3 tumor were inoculated intradermally $(3 \times$ $10^{5}$ cells per site) into syngeneic mice. Before inoculation, TMps were stimulated with the muscarinic agonist carbachol in the absence or presence of different muscarinic antagonists or enzyme inhibitors. Angiogenesis was evaluated by counting vessels per square millimeter of skin. The expression of $m A c h R$, arginase and cyclo-oxygenase (COX) isoforms was analyzed by Western blotting. Arginase and COX activities were evaluated by urea and prostaglandin $\mathrm{E}_{2}\left(\mathrm{PGE}_{2}\right)$ production, respectively.
\end{abstract}

Results TMps, which stimulate neovascularization, express functional $m A$ chR, because carbachol-treated TMps potently increased new blood vessels formation. This response was completely blocked by preincubating TMps with pirenzepine and 4-diphenylacetoxy- $N$-methylpiperidine (4-DAMP), $M_{1}$ and $M_{3}$ receptor antagonists, and partly by the $M_{2}$ receptor antagonist methoctramine. $M_{1}$ receptor activation by carbachol in TMps triggers neovascularization through arginase products because $N^{\omega}$-hydroxy-L-arginine reversed the agonist action. Preincubation of TMps with methoctramine partly prevented carbachol-stimulated urea formation. In addition, COX-derived liberation of $\mathrm{PGE}_{2}$ is responsible for the promotion of TMps angiogenic activity by $M_{3}$ receptor. We also detected a higher expression of vascular endothelial growth factor (VEGF) in TMps than in macrophages from normal mice. Carbachol significantly increased VEGF expression in TMps, and this effect was totally reversed by methoctramine and pirenzepine. Arginase and COX inhibitors partly decreased VEGF derived from TMps.

Conclusion TMps themselves induce a potent angiogenic response that is augmented by carbachol action. mAchR activation triggers arginine metabolism, $P G E_{2}$ synthesis and VEGF production, promoting neovascularization.

\section{Introduction}

Malignant tumors contain macrophages (Mps) as a major component of the host leukocytic infiltrate, and the role of Mps in tumor progression has generated contradictory evidence [1].
It has been recognized that Mps can act either as negative regulators by achieving tumor cytotoxicity or as positive regulators by promoting tumor growth. Neovascularization, an essential step in tumor progression and metastasis development, can

$\overline{\mathrm{COX}}=$ cyclo-oxygenase; 4 -DAMP $=4$-diphenylacetoxy- $N$-methylpiperidine; $\mathrm{FCS}=$ fetal calf serum; $\mathrm{IL}=$ interleukin; $\mathrm{kDa}=\mathrm{kilodaltons;} \mathrm{mAchR}=$ muscarinic acetylcholine receptor; $\mathrm{MEM}=$ minimal essential medium; Mps = macrophages; NBT/BCIP = nitro blue tetrazolium/5-bromo-4-chloroindol-3yl phosphate; NMps = peritoneal macrophages from normal mice; $\mathrm{NOHA}=N \omega$-hydroxy-L-arginine; PBS $=$ phosphate-buffered saline; $\mathrm{PGE} \mathrm{E}_{2}=$ prostaglandin $\mathrm{E}_{2} ; \mathrm{RIA}=$ radio-immunoassay; TBST = Tris-buffered saline containing Tween 20; TMps = peritoneal macrophages from LMM3 murine mammary adenocarcinoma-bearing mice; VEGF = vascular endothelial growth factor. 
be modulated by the presence of Mps in the tumor microenvironment. Angiogenic stimuli can proceed from tumor cells and/or immune cells such as lymphocytes and Mps. We have previously demonstrated the ability Mps from tumor-bearing mice to exacerbate the angiogenic response elicited by LMM3 tumor cells (derived from a murine mammary adenocarcinoma), confirmed by CD31 positivity at the angiogenic site [2]. There are several molecules, such as nitrogen metabolites, prostaglandins, vascular endothelial growth factor (VEGF), fibroblast growth factor and placental growth factor, that exert proangiogenic functions [3]. Less knowledge is available about the autonomic regulation of tumor neovascularization. Here we investigate the role of the parasympathetic nervous system on the angiogenic activity exerted by peritoneal Mps from 7-day LMM3 mammary-tumor-bearing mice (TMps) by studying the expression and function of muscarinic acetylcholine receptors (mAchRs) in new blood vessel formation induced by TMps.

\section{Materials and methods Animals and tumor cell line}

BALB/c mice (females 8 to 12 weeks old) from our Animal Care Division were used. Animal care was provided in accordance with the procedure outlined in the Guide for Care and Use of Laboratory Animals (NIH, 1986 edition). The tumor cell line LMM3 had previously been obtained from a spontaneous syngeneic mammary adenocarcinoma MM3 [4]. LMM3 cells were maintained as monolayers at $37^{\circ} \mathrm{C}$ in $5 \% \mathrm{CO}_{2}$ in MEM supplemented with 5\% FCS. Cells were detached with trypsin; only cell suspensions with more than $90 \%$ viability (assessed by Trypan blue) were used. Tumor-bearing mice were obtained by subcutaneous inoculation into the flank of 4 $\times 10^{5} \mathrm{LMM} 3$ cells.

\section{Purification of peritoneal macrophages}

Resident peritoneal cells from normal mice and tumor-bearing mice were obtained by washing the peritoneal cavity previously inoculated with $5 \mathrm{ml}$ of MEM supplemented with 10\% FCS. The adherent Mps population from normal mice (NMps) and from 7-day tumor-bearing mice (TMps) were purified by adhesion to plastic for 2 hours. After being washed twice with PBS, adherent cells were scraped and resuspended in culture medium. Cell viability was assessed by the Trypan blue exclusion test; only suspensions with more than $95 \%$ viability were used.

\section{Angiogenesis assay}

Mps and tumor cell-induced angiogenesis was quantified with an in vivo bioassay described previously [5]. In brief, tumor cell suspensions were prepared by detaching and washing LMM3 cells twice with fresh MEM. Cell concentration was adjusted to $3 \times 10^{6} \mathrm{cells} / \mathrm{ml}$ and female normal mice were inoculated intradermally in both flanks with $3 \times 10^{5} \mathrm{LMM} 3$ cells, NMps or TMps in a total volume of $0.1 \mathrm{ml}$ of MEM with a drop of Trypan blue to localize the site of inoculation. Before inoculation, Mps were treated for 1 hour with carbachol $(100 \mathrm{nM})$ in the absence or presence of $1 \mu \mathrm{M}$ atropine, $1 \mu \mathrm{M}$ pirenzepine, 1 $\mu \mathrm{M}$ methoctramine, $1 \mu \mathrm{M}$ 4-diphenylacetoxy- $N$-methylpiperidine (4-DAMP), $100 \mu \mathrm{M} N^{\omega}$-hydroxy-L-arginine (NOHA), $1 \mu \mathrm{M}$ indomethacin or $10 \mu \mathrm{M}$ NS-398. Cells were washed before inoculation. On day 5 , animals were killed with ether, the skin was carefully separated from the underlying tissues and the vascular response was observed with a dissecting microscope (Wild) at $\times 6.4$ magnification. The inoculated sites were photographed and the slides were projected on a reticular screen to count the number of vessels per $\mathrm{mm}^{2}$ of skin. Angiogenesis was quantified as vessel density $(\delta)$, calculated as the total number of vessels divided by the total number of squares.

\section{Detection of muscarinic acetylcholine receptor subtypes by Western blotting}

Purified Mps (106 cells) were lysed at $4^{\circ} \mathrm{C}$ with $0.5 \mathrm{ml}$ of $0.5 \%$ Nonidet P40, $10 \mathrm{mM}$ Tris- $\mathrm{HCl}, \mathrm{pH} 7.4,5 \mathrm{mM} \mathrm{MgCl} 2,50 \mathrm{mM}$ $\mathrm{NaCl}, 1 \mathrm{mM}$ EDTA, $1 \mathrm{mM}$ EGTA, $50 \mathrm{mM} \mathrm{NaF}, 0.1 \mathrm{mM}$ orthovanadate and the following protease inhibitors: $10 \mu \mathrm{g} / \mathrm{ml}$ aprotinin, $10 \mu \mathrm{g} / \mathrm{ml}$ leupeptin, $5 \mathrm{mM} \mathrm{PMSF}$ and $50 \mu \mathrm{g} / \mathrm{ml}$ soybean trypsin inhibitor. Lysates were sonicated for $30 \mathrm{~s}$ and centrifuged at 3,000 r.p.m. for $10 \mathrm{~min}$ at $4^{\circ} \mathrm{C}$. Supernatants were centrifuged at 10,000 r.p.m. for $20 \mathrm{~min}$ at $4^{\circ} \mathrm{C}$. The resulting supernatants were stored at $-80^{\circ} \mathrm{C}$. Protein concentration was determined by the Lowry method [6].

Samples were subjected to 7.5\% SDS-PAGE minigel electrophoresis, with $30 \mu \mathrm{g}$ of protein in each lane. Standards of known molecular masses were also seeded. After electrophoresis, proteins were transferred to a nitrocellulose membrane (Bio-Rad) and washed with distilled water. The nitrocellulose strips were blocked in buffer $(20 \mathrm{mM}$ Tris- $\mathrm{HCl}$, $500 \mathrm{mM} \mathrm{NaCl}, 0.05 \%$ Tween 20 (TBST) with 5\% skimmed milk) for 1 hour at 20 to $-25^{\circ} \mathrm{C}$ and subsequently incubated overnight with goat anti- $\mathrm{M}_{1}$, anti- $\mathrm{M}_{2}$ and anti- $\mathrm{M}_{3}$ polyclonal antibodies (Santa Cruz Biotechnology) diluted 1:100 in TBST. After several rinses with TBST, strips were incubated with the second antibody (goat anti-mouse IgG conjugated with alkaline phosphatase, diluted $1: 4,000$ in TBST) at $37^{\circ} \mathrm{C}$ for 1 hour. Bands were revealed with a mixture of nitro blue tetrazolium chloride and 5-bromo-4-chloroindol-3-yl phosphate $p$-toluidine salt (NBT/BCIP) [7]. Quantification of the bands was performed with a computerized densitometer connected to an image analyzer (Bio-Rad GS700) and is expressed in optical density units per $\mathrm{mm}^{2}$.

\section{Arginase activity assay}

Arginase activity was determined in cell lysates in accordance with methods described previously [8]. In brief, $10^{5}$ cells were treated or not with $100 \mathrm{nM}$ carbachol in the absence or presence of $100 \mu \mathrm{M}$ NOHA, $1 \mu \mathrm{M}$ atropine, $1 \mu \mathrm{M}$ pirenzepine, 1 $\mu \mathrm{M}$ methoctramine or $1 \mu \mathrm{M}$ 4-DAMP. After being washed, cells were lysed with $0.5 \mathrm{ml}$ of $0.1 \%$ Triton X-100, $25 \mathrm{mM}$ Tris$\mathrm{HCl}, \mathrm{pH} 7.4$, containing $5 \mathrm{mM} \mathrm{MnCl}_{2}$. The enzyme was then 
activated by being heated at $56^{\circ} \mathrm{C}$ for $10 \mathrm{~min}$. Arginine hydrolysis was performed by incubating $25 \mu \mathrm{l}$ of the activated lysate with $25 \mu \mathrm{l}$ of $0.5 \mathrm{M}$ arginine, $\mathrm{pH} 9.7$, at $37^{\circ} \mathrm{C}$ for $60 \mathrm{~min}$. The reaction was stopped in acid medium. Urea concentration was measured at $540 \mathrm{~nm}$ with a microplate reader. Results are expressed as micromoles of urea per hour per million cells.

\section{Detection of arginase isoforms by Western blotting}

Mps were rinsed twice with ice-cold PBS and then scraped into $300 \mu \mathrm{l}$ lysis buffer $(50 \mathrm{mM}$ Tris- $\mathrm{HCl}, \mathrm{pH} 7.5,0.1 \mathrm{mM}$ EDTA, $0.1 \mathrm{mM}$ EGTA, $1 \mu \mathrm{g} / \mathrm{ml}$ leupeptin, $1 \mu \mathrm{g} / \mathrm{ml}$ aprotinin and $0.1 \mathrm{mM}$ PMSF). Lysis was completed by sonication. Samples $(25 \mu \mathrm{g})$ were subjected to $10 \%$ SDS-PAGE as described previously [9-11]. Nitrocellulose membranes were incubated overnight with a monoclonal anti-mouse arginase I antibody (BD Transduction Laboratories) or with a rabbit anti-arginase II antibody (a gift from Dr Masataka Mori). The secondary antibody anti-mouse or anti-rabbit IgG conjugated with alkaline phosphatase was added for 1 hour at $37^{\circ} \mathrm{C}$. Proteins were revealed with NBT/BCIP and quantified by a densitometric analysis.

\section{Prostaglandin $E_{\mathbf{2}}$ assay}

Prostaglandin $\mathrm{E}_{2}\left(\mathrm{PGE}_{2}\right)$ production by Mps was determined by RIA as described previously [12]. Purified Mps $\left(2 \times 10^{6}\right.$ cells per sample) were incubated for 1 hour at $37^{\circ} \mathrm{C}$ in a Dubnoff bath with carbogen in $1 \mathrm{ml}$ of MEM with or without $100 \mathrm{nM}$ carbachol in the absence or presence of $1 \mu \mathrm{M}$ atropine, $1 \mu \mathrm{M}$ methoctramine or $1 \mu \mathrm{M}$ 4-DAMP, $1 \mu \mathrm{M}$ indomethacin or $10 \mu \mathrm{M}$ NS-398. After incubation, cells were centrifuged for $10 \mathrm{~min}$ at $200 \mathrm{~g}$ and supernatants were frozen at $-80^{\circ} \mathrm{C}$ until the assay was performed. For $\mathrm{PGE}_{2} \mathrm{RIA}, 100 \mu \mathrm{I}$ samples or standards were incubated for $30 \mathrm{~min}$ with $500 \mu \mathrm{l}$ of rabbit anti-PGE ${ }_{2}$ antiserum (Sigma) at $4^{\circ} \mathrm{C}$. Then $5 \mathrm{pg}$ of $\left[{ }^{3} \mathrm{H}\right] \mathrm{PGE}_{2}$ (specific radioactivity $154 \mathrm{Ci} / \mathrm{mmol}$; New England Nuclear) was added to each tube. All dilutions were performed in $0.01 \mathrm{M}$ PBS, $\mathrm{pH} 7.4$, containing $0.1 \% \mathrm{BSA}$ and $0.1 \%$ sodium azide. After incubation, a dextran-coated charcoal suspension was added to separate the bound and free fractions. The supernatants were removed from each tube and scintillation solution (Optiphase Hisafe 3; Wallac) was added to determine the amount of radioactivity present. Results are expressed in picograms per $10^{5}$ cells.

\section{Detection of cyclo-oxygenase (COX) isoforms by Western blotting}

Purified Mps were washed twice in cold PBS and then resuspended in $300 \mu$ l of lysis buffer $(20 \mathrm{mM}$ Tris-HCl, $1 \mathrm{mM}$ EDTA, $10 \mu \mathrm{g} / \mathrm{ml}$ leupeptin, $2 \mu \mathrm{g} / \mathrm{ml}$ aprotinin, $10 \mu \mathrm{g} / \mathrm{ml}$ dithiotreitol, $100 \mu \mathrm{g} / \mathrm{ml}$ soybean trypsin inhibitor, $1 \mathrm{mg} / \mathrm{ml}$ benzamidine). After 1 hour, lysates were centrifuged at 5,000 r.p.m. for 10 $\mathrm{min}$. The resulting supernatants were stored at $-80^{\circ} \mathrm{C}$. Protein concentration was determined by the Lowry method [6].
Samples were subjected to 7.5\% SDS-PAGE minigel electrophoresis, with $30 \mu \mathrm{g}$ of protein in each lane. Standards of known molecular masses were also seeded. After electrophoresis, proteins were transferred to a nitrocellulose membrane (Bio-Rad) at $4^{\circ} \mathrm{C}$ for 18 hours. Membranes were then washed with distilled water and incubated with blocking solution (5\% skimmed milk in TBST) for 1 hour at 20 to $-25^{\circ} \mathrm{C}$. Membranes were incubated with rabbit polyclonal anti-COX-1 or anti-COX-2 antibodies (Cayman Chemical) in Tris-buffered saline for $90 \mathrm{~min}$ at room temperature. Then secondary antirabbit IgG antibody conjugated with alkaline phosphatase was added for 1 hour at $37^{\circ} \mathrm{C}$. Proteins were revealed with NBT/ $\mathrm{BCIP}$ and quantified by a densitometric analysis [13].

\section{Detection of VEGF by Western blotting}

Production of VEGF was measured in lysates from untreated TMps or TMps treated with $100 \mathrm{nM}$ carbachol for 1 hour in the absence or presence of $1 \mu \mathrm{M}$ atropine, $1 \mu \mathrm{M}$ pirenzepine, 1 $\mu \mathrm{M}$ methoctramine or $1 \mu \mathrm{M} 4$-DAMP or the enzyme inhibitors $100 \mu \mathrm{M}$ NOHA, $1 \mu \mathrm{M}$ indomethacin or $10 \mu \mathrm{M}$ NS-398. Cells were then cultured without FCS at $37^{\circ} \mathrm{C}$ for 24 hours in 100 $\mathrm{mm}$ Petri dishes. After being washed twice with cold PBS, TMps were lysed in $10 \mathrm{mM}$ Tris- $\mathrm{HCl}, \mathrm{pH} 8,1 \%$ Triton X-100, $100 \mathrm{mM} \mathrm{NaCl}, 10 \mathrm{mM}$ EGTA, $10 \mathrm{mM}$ EDTA, with protease inhibitors ( $1 \mathrm{mM}$ PMSF, $10 \mu \mathrm{g} / \mathrm{ml}$ leupeptin, $10 \mu \mathrm{g} / \mathrm{ml}$ aprotinin). After 1 hour in an ice bath, lysates were centrifuged at 10,000 r.p.m. for $10 \mathrm{~min}$ at $4^{\circ} \mathrm{C}$. Samples were subjected to $10 \%$ SDS-PAGE electrophoresis. Proteins were transferred to nitrocellulose membranes and, after several rinses with doubly distilled water, were blocked with $5 \%$ skimmed fat milk in TBST buffer. The primary antibody (goat polyclonal anti-VEGF; Santa Cruz Biotechnology) was added for 18 hours, and the secondary antibody anti-goat $\lg G$ conjugated with alkaline phosphatase was added for 1 hour at $37^{\circ} \mathrm{C}$. Proteins were detected with NBT/BCIP and quantified by densitometric analysis $[13,14]$.

\section{Drugs}

All drugs were purchased from Sigma-Aldrich unless otherwise stated. Solutions were prepared fresh daily.

\section{Statistics}

Results are given as means \pm SEM for at least three independent experiments. The statistical significance of differences between groups was analyzed by analysis of variance, Tukey's modified $t$-test or the Mann-Whitney test, using the STAT PRIMER program; $P<0.05$ was considered to be statistically significant.

\section{Results \\ Carbachol stimulates angiogenesis induced by TMps}

We have reported previously that a small number of TMps (2 $\times 10^{3}$ to $2 \times 10^{4}$ cells) from 7-day LMM3 tumor-bearing mice were unable to induce an angiogenic response in syngeneic mice. The vessel density $(\delta)$ of mice inoculated with TMps $(\delta=$ 
Table 1

Participation of mAchR subtypes in angiogenesis induced by TMps

\begin{tabular}{|c|c|c|}
\hline Treatment & Angiogenic response (vessels $\left./ \mathrm{mm}^{2}\right)$ & $n$ \\
\hline None & $2.33 \pm 0.07$ & 5 \\
\hline CARB & $4.98 \pm 0.40^{\star \star}$ & 5 \\
\hline AT + CARB & $2.57 \pm 0.25$ & 5 \\
\hline PIR + CARB & $2.49 \pm 0.63$ & 4 \\
\hline MET + CARB & $3.35 \pm 0.17^{\star}$ & 5 \\
\hline 4-DAMP + CARB & $2.64 \pm 0.48$ & 6 \\
\hline
\end{tabular}

Peritoneal macrophages $\left(3 \times 10^{5}\right)$ from 7-day LMM3 tumor-bearing mice (TMps) untreated or stimulated with carbachol (CARB; $\left.100 \mathrm{nM}\right)$ in the absence or presence of $1 \mu \mathrm{M}$ atropine (AT), pirenzepine (PIR), methoctramine (MET) or 4-diphenylacetoxy- $N$-methylpiperidine (4-DAMP) were inoculated intradermally into normal mice to evaluate the angiogenic response. ${ }^{\star \star} P<0.0001,{ }^{\star} P<0.05$ compared with untreated TMps (MannWhitney test). $n$, number of sites evaluated. Results are means \pm SEM for three experiments.

Table 2

Participation of arginase and COX in angiogenesis induced by TMps

\begin{tabular}{lcc}
\hline Treatment & Angiogenic response (vessels $\left./ \mathrm{mm}^{2}\right)$ & $n$ \\
\hline None & $2.34 \pm 0.06$ & 5 \\
CARB & $4.96 \pm 0.41^{*}$ & 5 \\
NOHA + CARB & $2.4 \pm 0.6$ & 4 \\
INDO + CARB & $1.9 \pm 0.92$ & 8 \\
NS-398 + CARB & $1.3 \pm 0.31$ & 5 \\
\hline
\end{tabular}

Peritoneal macrophages $\left(3 \times 10^{5}\right)$ from 7-day LMM3 tumor-bearing mice (TMps) stimulated with carbachol (CARB; $\left.100 \mathrm{nM}\right)$ in the absence or presence of $N^{\omega}$-hydroxy-L-arginine (NOHA; $100 \mu \mathrm{M}$ ), indomethacin (INDO; $\left.1 \mu \mathrm{M}\right)$ or NS-398 $(10 \mu \mathrm{M})$ were inoculated intradermally into normal mice to evaluate the angiogenic response. ${ }^{\star} P<0.001$ compared with control (without treatment) (Mann-Whitney test). $n$, number of sites evaluated. Results are means \pm SEM for three experiments.

$1.70 \pm 0.15)$ was not significantly different from that observed in normal skin $(\delta=1.65 \pm 0.20)$. In larger numbers $\left(3 \times 10^{5}\right)$, TMps elicit positive angiogenesis $(\delta=2.84 \pm 0.06)$, similar to that observed with the same number of LMM3 tumor cells ( $\delta$ $=2.91 \pm 0.38$ ). The addition of $100 \mathrm{nM}$ carbachol increased the neovascularization induced by TMps by $112 \%$ (Table 1 ). The participation of $\mathrm{mAchR}$ was confirmed by blunting the carbachol action with $1 \mu \mathrm{M}$ atropine. Peritoneal NMps were unable to induce angiogenesis: the neovascular response $(\delta=$ $1.86 \pm 0.55)$ was similar to that observed in normal skin. The addition of carbachol, at the same dose, did not modify the density of blood vessels $(\delta=1.80 \pm 0.46)$.

We then investigated the participation of mAchR subtypes in neovascularization induced by TMps. As shown in Table 1, blockade of $\mathrm{M}_{1}$ or $\mathrm{M}_{3}$ receptors with $1 \mu \mathrm{M}$ pirenzepine or 4DAMP, respectively, completely abolished the stimulatory effect of carbachol on angiogenesis, whereas preincubation with $1 \mu \mathrm{M}$ methoctramine (an $\mathrm{M}_{2}$ antagonist) partly prevented the carbachol action.

\section{Arginase and COX products are involved in angiogenesis induced by TMps}

Table 2 summarizes results indicating that preincubating TMps with $100 \mu \mathrm{M}$ NOHA, $1 \mu \mathrm{M}$ indomethacin or $10 \mu \mathrm{M}$ NS398 significantly blunted carbachol-stimulated angiogenesis, demonstrating the participation of arginase and COX in this effect.

We have previously reported that arginase I and II were constitutively expressed in Mps, and their expression and activity were upregulated in TMps in comparison with NMps. Our present results indicate that carbachol, at the same dose that triggers neovascularization, increases urea formation (Fig. 1). This overproduction was completely reversed by NOHA (100 $\mu \mathrm{M})$, an enzyme-specific inhibitor of arginase. mAchR activation was also blunted by $1 \mu \mathrm{M}$ atropine or with $1 \mu \mathrm{M}$ pirenzepine, indicating a relation between $M_{1}$ receptor subtype activation and arginase as its effector enzyme. It is also shown in Fig. 1 that the $M_{2}$ selective antagonist methoctramine partly blunted the action of carbachol. Preincubation of TMps with 4DAMP did not modify the action of carbachol on urea formation (78 $\pm 7 \mu \mathrm{mol} / \mathrm{h}$ per $10^{6}$ cells). Western blotting therefore shows the presence of $M_{1}$ and $M_{2}$ receptor proteins in the membrane-enriched fraction of TMps (Fig. 1). 
Figure 1

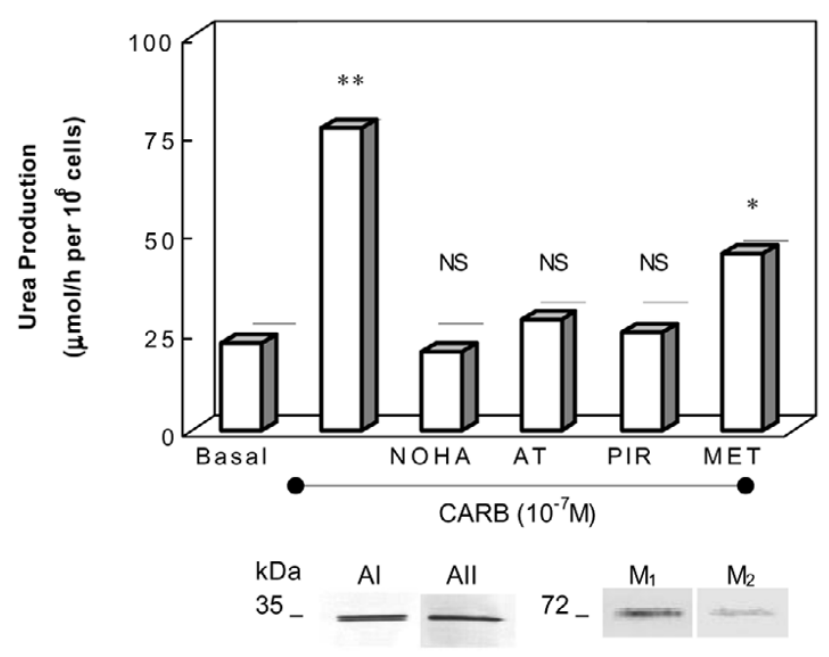

Arginase and muscarinic receptors in TMps. Upper panel: macrophages from 7-day LMM3 tumor-bearing mice (TMps) were treated with carbachol (CARB) $(100 \mathrm{nM})$ in the absence or presence of $100 \mu \mathrm{M}$ $N^{\omega}$-hydroxy-L-arginine (NOHA), $1 \mu \mathrm{M}$ atropine (AT), pirenzepine (PIR) or methoctramine (MET). Arginase activity was measured by urea production as $\mu \mathrm{mol} / \mathrm{h}$ per $10^{6}$ cells. Values are means \pm SEM for five experiments. ${ }^{\star \star} P<0.001,{ }^{\star} P<0.05$ compared with basal; NS, not significantly different from basal by Tukey's modified $t$-test. Lower panel: Western blot assay to detect arginase isoforms and muscarinic receptors $(\mathrm{M})$ in lysates of TMps. The molecular masses of the bands indicated on the left are coincident with arginase I, II and $M_{1}$ and $M_{2}$ proteins. One representative experiment of three is shown.

Prostaglandins are important mediators in tumor progression because they promote tumor growth and immunosuppress tumor hosts. Here we show that $100 \mathrm{nM}$ carbachol markedly increased the liberation of $\mathrm{PGE}_{2}$ by TMps (Fig. 2). This stimulatory action was inhibited by preincubating cells with $1 \mu \mathrm{M}$ indomethacin or with $10 \mu \mathrm{M}$ NS-398, a non-selective COX inhibitor and a COX-2-selective inhibitor, respectively. In addition, we observed that $M_{3}$ receptor subtype is involved in carbachol-induced $\mathrm{PGE}_{2}$ liberation: not only did $1 \mu \mathrm{M}$ atropine blunt the agonist action, but a $1 \mu \mathrm{M}$ 4-DAMP blockade was also effective (Fig. 2). Neither pirenzepine (2,879 $\pm 181 \mathrm{pg}$ of $\mathrm{PGE}_{2} / 10^{6}$ cells $)$ nor methoctramine $(2,799 \pm 197 \mathrm{pg} \mathrm{PGE} /$ $10^{6}$ cells) modified carbachol-induced $\mathrm{PGE}_{2}$ liberation. We also detected $M_{3}$ receptor subtype expression in the TMps membrane-enriched fraction by Western blotting (Fig. 2).

\section{Participation of VEGF in angiogenesis induced by TMps}

Several growth factors and/or cytokines are involved in tumor angiogenesis. VEGF is the most extensively studied. Here we measured VEGF expression in lysates of Mps. Western blot experiments indicate that TMps express larger amounts of VEGF than NMps do (Fig. 3a). In addition, carbachol significantly increases VEGF derived from TMps. Preincubation of cells with $1 \mu \mathrm{M}$ methoctramine or pirenzepine blocked the action of carbachol on VEGF expression, whereas $1 \mu \mathrm{M} 4$ DAMP was ineffective in preventing agonist action. When
Figure 2

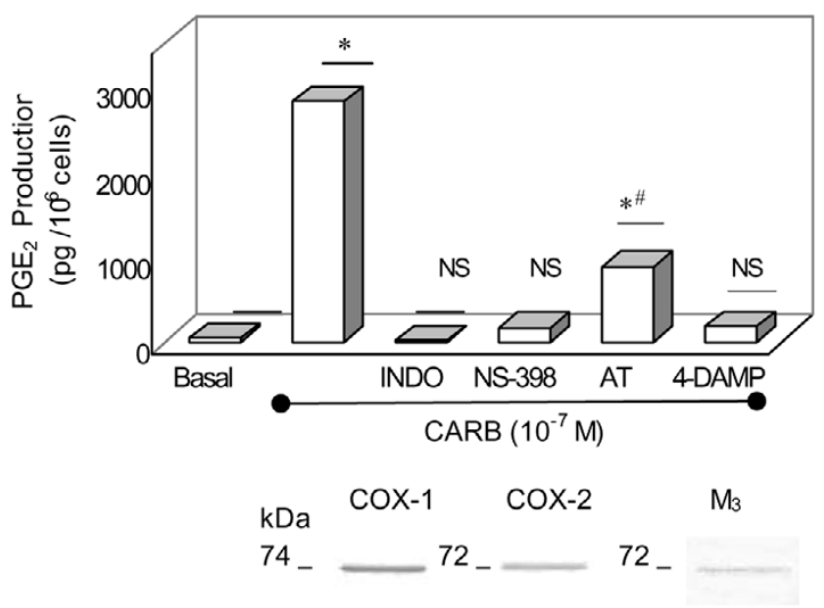

Cyclo-oxygenase (COX) muscarinic receptors in TMps. Upper panel: macrophages from 7-day LMM3 tumor-bearing mice (TMps) were treated with carbachol (CARB) $(100 \mathrm{nM})$ in the absence or presence of $1 \mu \mathrm{M}$ indomethacin (INDO) $10 \mu \mathrm{M} \mathrm{NS}-398,1 \mu \mathrm{M}$ atropine (AT) or 4DAMP. COX activity was measured by prostaglandin $E_{2}\left(P E_{2}\right)$ liberation by TMps as $\mathrm{pg} / 10^{6}$ cells. Values are means \pm SEM for three experiments. ${ }^{*} P<0.001$ compared with basal; $\# P<0.001$ compared with CARB; NS, not significantly different from basal by Tukey's modified $t$ test. Lower panel: Western blot assay to detect COX isoforms and muscarinic receptors (M) in lysates of TMps. Molecular masses of the bands indicated on the left are coincident with COX-1, COX-2 and $M_{3}$ proteins. One representative experiment of three is shown.

TMps were treated with $100 \mu \mathrm{M}$ NOHA, $10 \mu \mathrm{M}$ NS-398 or 1 $\mu \mathrm{M}$ indomethacin, VEGF protein expression was decreased by almost 30\% (Fig. 3b).

\section{Discussion}

Mps perform multiple functions that are essential in tissue remodeling, wound healing, inflammation and immunity. These cells form the major component of the mononuclear leukocyte population of some solid tumors $[1,15]$. In the 1980s, Polverini and Leibovich demonstrated that tumor-associated Mps isolated from 3-methycholanthrene-induced rat fibrosarcoma were potent stimulators of in vivo neovascularization and bovine endothelial cell proliferation; depletion of Mps from tumor cell suspensions significantly decreased their angiogenic potential, suggesting that neovascularization was mediated in part by Mps [16].

Taking into account the fact that murine mammary adenocarcinomas arising spontaneously in BABL/c mice in our laboratory are poorly infiltrated by Mps, we showed that peritoneal Mps from 7-day tumor-bearing mice, when present at low concentrations, contribute to the enhancement of LMM3 angiogenesis by providing polyamine precursors to tumor cells [2]. Although the origin of tumor-infiltrating Mps has been discussed extensively, evidence supports both recruitment from the circulating pool of monocytes and the proliferation of the 
(a)

\begin{tabular}{rrr}
$\mathrm{kDa}$ & NMps & TMps \\
\hline $45-$ & \multicolumn{1}{c}{} & \\
$\mathrm{OD} / \mathrm{mm}^{2}$ & 0.065 & 0.081
\end{tabular}

(b)

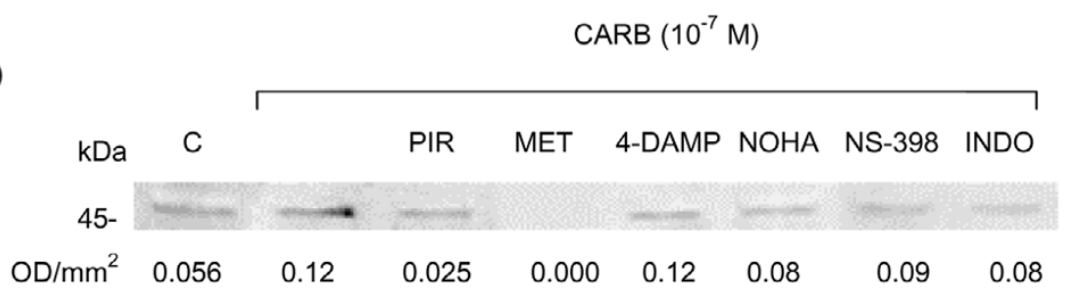

Western blot assay to detect vascular endothelial growth factor (VEGF) expression. (a) Expression in normal macrophages (NMps) and macrophages from 7-day LMM3 tumor-bearing mice (TMps). (b) TMps were treated with carbachol (CARB) (100 nM) in the absence or presence of $1 \mu \mathrm{M}$ pirenzepine (PIR), methoctramine (MET) or 4-DAMP. Lane C, control (TMps without treatment). Bands were quantified in optical density units per square millimeter $\left(\mathrm{OD} / \mathrm{mm}^{2}\right)$. The molecular mass indicated at the left corresponds to the VEGF isoform detected. One representative experiment of three is shown.

local Mps population, and it has recently been discussed that Mps could become angiogenic in the presence of diverse stimuli such as growth factors or low oxygen tension as well as soluble tumor antigens $[17,18]$. Here we show that peritoneal TMps, when inoculated in a number equal to that of LMM3 tumor cells, themselves elicit a potent angiogenic response. In contrast, 'unstimulated' NMps did not promote angiogenesis in our model. Further investigation is required to determine whether TMps activation occurs in the host-tumor interface or can be triggered at distance by soluble cytokines and/or tumor antigens.

Other authors have shown that the levels and functions of lymphocytes, granulocytes, Mps and natural killer cells are under the regulation of the autonomic nervous system [19]. We showed that the activation of $\mathrm{mAchR}$ in TMps by the cholinergic agonist carbachol increases their angiogenic ability. The participation of muscarinic receptors was demonstrated by preincubating cells with the non-selective muscarinic antagonist atropine. Angiogenesis is now considered an important step during inflammation and cancer, and it might be necessary as a local, protective response against invasion by pathogens and the proliferation of transformed cells. It is also important in tumor growth and metastasis. The nervous system reflexively regulates the inflammatory response and it has been recently documented that acetylcholine, the principal vagal neurotransmitter, significantly attenuates the release of cytokines (tumor necrosis factor, IL-1, IL-6 and IL-18, but not the anti-inflammatory cytokine $\mathrm{IL}-10$ ) in lipopolysaccharidestimulated human macrophage cultures [20]. These antiinflammatory actions are generally related to nicotinic receptor stimulation [21]. In our model, mAchR stimulation seems to be promoting pro-inflammatory actions by stimulating angiogenesis induced by TMps. It remains to be tested whether the acti- vation of nicotinic receptors in TMps might be exerting antiinflammatory actions.

$M_{1}, M_{2}$ and $M_{3}$ antagonists decreased the carbachol stimulation of neovascularization induced by TMps, showing a collaborative activation of different mAchR subtypes in the neovascular response. It has recently been documented that different $m A$ chR activation controls different functions in distinct systems simultaneously. The activation of $M_{1}$ and $M_{3}$ receptors by carbachol induces pigment granule dispersion in isolated retinal pigment epithelium from bluegill. Carbacholinduced pigment granule dispersion is blocked by the muscarinic antagonist atropine, by the $M_{1}$ antagonist pirenzepine and by the $\mathrm{M}_{3}$ antagonist 4-DAMP [22]. We also showed that the activation of $M_{1}, M_{2}$ and $M_{3}$ receptors by carbachol is involved in the proliferation of two different murine mammary adenocarcinoma cell lines, LM3 and LM2 [23].

The carbachol stimulation of angiogenesis induced by TMps occurs by the signaling of $M_{1}$ to arginase, because pirenzepine totally blocked the carbachol stimulation of urea production. Arginase I and II are overexpressed in TMps in comparison with NMps and are involved in the positive modulation by TMps of angiogenesis induced by LMM3 mammary tumor cells [2]. We were the first to report that carbachol was able to stimulate the proliferation of tumor cells by arginine metabolism through arginase linked to $M_{1}$ receptors in LM2 cells, derived from M2 murine mammary adenocarcinoma [23].

We also observed that methoctramine partly blunted carbachol-stimulated vascularization and urea formation, indicating that $\mathrm{M}_{2}$ receptors are also involved in this effect. We have previously documented a collaborative action of $\mathrm{M}_{2}$ and $\mathrm{M}_{3}$ receptor activation by carbachol, which increases amylase secretion 
in lipopolysaccharide-inflamed salivary glands by stimulating $\mathrm{PGE}_{2}$ liberation [7]. We are therefore reporting that the expression and function of $M_{1}$ and $M_{2}$ receptors are involved in the control of angiogenesis induced by TMps, by stimulating polyamine synthesis in these cells.

The tumor microenvironment is rich in inflammatory cytokines, growth factors and chemokines, but generally poor in cytokines associated with a sustained immune antitumor response. It is now accepted that tumor-associated Mps produce soluble mediators that contribute to tumor progression. Our results indicate that the parasympathetic nervous system positively modulates neovascularization induced by TMps by stimulating $M_{3}$ receptors and $P G E_{2}$ liberation. Because indomethacin and NS-398 blunted the carbachol action on $\mathrm{PGE}_{2}$ synthesis, the COX-1 and COX-2 isoenzymes are involved in angiogenesis induced by TMps. In particular, COX2 protein expression is highly upregulated in TMps in comparison with NMps (data not shown). Several authors have stated that there is a role of COX-2 expression and function not only in tumors but also in immune cells from the host $[14,18,25]$. The overproduction of this prostanoid could be responsible for an autocrine loop that also promotes immunosuppression of the host.

Previous results indicate that activation of G-protein-coupled receptors encoded by Kaposi's sarcoma-associated herpesvirus could be increasing VEGF expression and promoting an angiogenic response that characterizes Kaposi's sarcoma lesions [26]. In support of this view, we observed that stimulation of $\mathrm{mAchR}$ in TMps by carbachol increased the $45 \mathrm{kDa}$ isoform of VEGF. This effect is linked to activation of the $\mathrm{M}_{2}$ and $M_{1}$ receptors, which in turn promote the arginine metabolic pathway through arginase. We have previously observed that the arginase pathway is involved in the angiogenic response induced by LMM 3 cells derived from a murine mammary adenocarcinoma. These cells, which exert a potent angiogenic response quantitatively similar to that induced by TMps, also produce significant amounts of VEGF [13]. Our results show that VEGF production by TMps depends partly on arginase metabolism because NOHA decreases VEGF production. Pretreatment of cells with COX inhibitors also diminished VEGF derived from TMps. In this way, the expression of COX1 and COX-2 and their product $\mathrm{PGE}_{2}$ has been shown to be promoters of angiogenesis by modulating the synthesis of various factors, including VEGF $[13,27]$. It must be taken into account that the stimulation of VEGF expression by COXderived $P G E_{2}$ in TMps is independent of $M_{3}$ receptor activation.

\section{Conclusion}

Here we propose a new mechanism involved in angiogenesis induced by peritoneal TMps through mAchR activation sustained by the formation of arginase products and $P G E_{2}$, which could be acting as promoters of the stimulation by VEGF of endothelial cell proliferation, vessel sprouting and organization during tumor progression or metastasis.

\section{Competing interests}

The author(s) declare that they have no competing interests.

\section{Authors' contributions}

$E$ de la $T$ performed the Western blot assays, LD performed the in vivo angiogenesis experiments and the statistical analysis, MAJ made helpful criticism in discussion, TG developed the anti-arginase II antibody, ESL participated in the study design and coordination, and MES performed RIAs and conceived of the study, and participated in its design and coordination. All authors read and approved the final manuscript.

\section{Acknowledgements}

This work was supported by the following grants: PEI 6335 from the National Research Council (CONICET), UBACYT M052 from the University of Buenos Aires and Premio a la Investigación en Bioquímica Molecular y Proteómica, Escuelas ORT, 2004.

\section{References}

1. Mantovani A, Bottazzi B, Colotta F, Sozzani S, Ruco L: The origin and function of tumor-associated macrophages. Immunol Today 1992, 13:265-270.

2. Davel L, Jasnis M, de la Torre E, Gotoh T, Diament M, Magenta G, Sacerdote de Lustig E, Sales ME: Arginine metabolic pathways involved in the modulation of tumor-induced angiogenesis by macrophages. FEBS Lett 2002, 532:216-220.

3. Carmeliet P, Jain RK: Angiogenesis in cancer and other diseases. Nature 2000, 407:249-257.

4. Urtreger AJ, Ladeda VE, Puricelli LI, Vidal MC, Sacerdote de Lustig $\mathrm{E}, \mathrm{Bal}$ de Kier Joffé $\mathrm{E}$ : Modulation of fibronectin expression and proteolytic activity associated with the invasive and metastatic phenotype in two murine mammary tumor cell lines. Int J Oncol 1997, 11:489-496.

5. Monte M, Davel L, Sacerdote de Lustig E: Hydrogen peroxide is involved in lymphocyte activation mechanisms to induce angiogenesis. Eur J Cancer 1997, 33:676-682.

6. Lowry OH, Rosebrough NJ, Farr AL, Randall RJ: Protein measurement with the Folin phenol reagent. J Biol Chem 1951, 193:265-275.

7. Español A, de la Torre E, Sales ME: Parasympathetic modulation of local acute inflammation in murine submandibular glands. Inflammation 2003, 27:97-105.

8. Modolell M, Corraliza IM, Link F, Soler G, Eichmann K: Reciprocal regulation of the nitric oxide synthase/arginase balance in mouse bone marrow-derived macrophages by $\mathrm{TH} 1$ and $\mathrm{TH} 2$ cytokines. Eur J Immunol 1995, 25:1101-1104.

9. Gotoh T, Sonoki J, Nagasaki A, Terada V, Taakiguchi M, Mori M: Molecular cloning of CDNA for nonhepatic mitochondrial arginase (arginase II) and comparison of its induction with nitric oxide synthase in a murine macrophage-like cell line. FEBS Lett 1996, 395:119-122.

10. Gotoh T, Mori M: Arginase II downregulates nitric oxide (NO) production and prevents NO-mediated apoptosis in murine macrophage-derived RAW 264.7 cells. J Cell Biol 1999, 144:427-434.

11. Que LG, George SE, Gotoh T, Mori M, Huang YC: Effects of arginase isoforms on NO production by nNOS. Nitric Oxide 2002, 6:1-8.

12. Davel L, D'Agostino A, Español AJ, Jasnis MA, Lauria de Cidre L, Sacerdote de Lustig E, Sales ME: Nitric oxide synthase-cyclooxygenase interactions are involved in tumor cell angiogenesis and migration. $J$ Biol Regul Homeost Agents 2002, 16:181-189.

13. Davel $L$, Rimmaudo $L$, Español $A$, de la Torre $E$, Jasnis MA, Ribeiro ML, Gotoh T, Sacerdote de Lustig E, Sales ME: Different mechanisms lead to the angiogenic process induced by three adenocarcinoma cell lines. Angiogenesis 2004, 7:45-51. 
14. Berse B, Brown LF, Van de Water L, Dvorak HF, Senger DR: Vascular permeability factor (vascular endothelial growth factor) gene is expressed differentially in normal tissues, macrophages and tumors. Mol Biol Cell 1992, 3:211-220.

15. Van Ravenswaay Claasen HH, Kluin PM, Fleuren GJ: Tumor infiltrating cells in human cancer. On the possible role of CD16+ macrophages in antitumor cytotoxicity. Lab Invest 1992, 67:166-174.

16. Polverini PJ, Leibovich SI: Induction of neovascularization in vivo and endothelial proliferation in vitro by tumor associated macrophages. Lab Invest 1984, 51:635-642.

17. McBride WH: Phenotype and functions of intratumoral macrophages. Biochim Biophys Acta 1986, 865:27-41.

18. Ohno S, Suzuki N, Ohno Y, Inagawa H, Soma Gl, Inoue M: Tumorassociated macrophages: foe or accomplice of tumors? Anticancer Res 2003, 23:4395-4409.

19. Rinner I, Schauenstein K: Detection of choline-acetyltransferase activity in lymphocytes. J Neurosci Res 1993, 35:188-191.

20. Borovikova LV, Ivanova S, Zhang M, Yang H, Botchkina GI, Watkins LR, Wang H, Abumrad N, Eaton JW, Tracey KJ: Vagus nerve stimulation attenuates the systemic inflammatory response to endotoxin. Nature 2000, 405:458-462.

21. Wang H, Yu M, Ochani M, Amella CA, Tanovic M, Susarla S, Li JH, Wang $\mathrm{H}$, Yang $\mathrm{H}$, Ulloa $\mathrm{L}$, et al.: Nicotinic acetylcholine receptor $\alpha 7$ subunit is an essential regulator of inflammation. Nature 2003, 421:384-388.

22. Gonzalez A, Crittenden EL, Garcia DM: Activation of muscarinic receptors elicits pigment granule dispersion in retinal pigment epithelium isolated from bluegill. BMC Neurosci 2004, 5:23.

23. Español AJ, Sales ME: Different muscarinic receptors are involved in the proliferation of murine mammary adenocarcinoma cell lines. Int J Mol Med 2004, 13:311-317.

24. Fitzpatrick FA: Inflammation, carcinogenesis and cancer. Int Immunopharmacol 2001, 1:1651-1667.

25. Soslow RA, Dannenberg AJ, Rush D, Woerner BM, Khan KN, Masferrer J, Koki AT: Cox-2 is expressed in human pulmonary, colonic, and mammary tumors. Cancer 2000, 89:2637-2645.

26. Sodhi A, Montaner S, Patel V, Zohar M, Bais C, Mesri EA, Gutkind JS: The Kaposi's sarcoma-associated herpes virus $G$ proteincoupled receptor up-regulates vascular endothelial growth factor expression and secretion through mitogen-activated protein kinase and p38 pathways acting on hypoxia-inducible factor1 $\alpha$. Cancer Res 2000, 60:4873-4880.

27. Joo YE, Rew JS, Seo YH, Choi SK, Kim YJ, Park CS, Kim SJ: Cyclooxygenase-2 overexpression correlates with vascular endothelial growth factor expression and tumor angiogenesis in gastric cancer. J Clin Gastroenterol 2003, 37:28-33. 